\title{
Research on Multidimensional Interaction Teaching Mode of College English Oriented by the Innovation, Critical Thinking, Cross-cultural Communicative Competence*
}

\author{
Zhengfeng Chen \\ Xi'dian University \\ Xi'an, China
}

\begin{abstract}
With the current information technology and foreign language classroom integration background, this article deals with college English teaching model of multidimensional interaction and the improvement of the efficiency of classroom teaching which is oriented by the innovation, critical thinking, intercultural communicative competence on the basis of the constructiveness and the multidimensional theory. Furthermore, it explores how the teachers make full use of multimedia network and fully display the role of students in the classroom as the students centered. Thus the multidimensional interactive teaching mode of teachers and students, students and students, students and learning content can be achieved. Moreover, the ability of innovation, critical thinking and intercultural communicative competence for students can be fulfilled, which meets the demands of the times and the social needs for talents.
\end{abstract}

Keywords-innovation; critical thinking; cross-cultural communication; multidimensional interaction

\section{INTRODUCTION}

After information technology represented by computer networks integrated with the foreign language classroom, how to make full use of cyber sources to supplement teaching contents, enrich teaching methods and improve teaching effect has become a hot topic of current English teaching research. Having experiencing the transformation from the chalkboard and the multimedia to the modern network and information technology, campus classroom environment inevitably altered students' learning styles. With this trend, proper adjustments about teaching methods should be made in order to make the best use of the advantages and bypass the disadvantages. However, there are a few difficulties faced by multimedia and network classroom: purely piling up multimedia materials will hinder students from digesting the contents of English class; intermittent

*[Fund Project] Shaanxi Education Science Program (SGH17H050) in 2017: The Research on the Construction of O2O College English Teaching Model in the Post- MOOC Era; Xi'an Social Science Fund Project

(17Y27) in 2017: Cultural Confidence Studies of College English Teaching in Xi'an under the Background of Internationalization; Key funding projects for special funds for basic scientific research in central colleges (RW170403) in 2017. presentation of multimedia will cut up the contextual relationship of teaching contents; the multimedia console which is fixed on the platform will limit the teachers performance during the class; unified and changeless seat layout will be detrimental to carry out various types of teaching activities; the outfit in network classroom is hard to meet learners' research needs; too much emphasis on training their test-taking skills, teachers will neglect to develop students' practical ability in language application. Generally speaking, there exists a gap between the effect of current college English teaching and the expected depth of teaching. The weakening of college English classroom activities leads to the students' lack of ability to think and innovate, which is not conducive to the cultivation of students' communicative competence. The "English language teaching" curriculum requires "to inspire students' thinking, let them be creative, help them build a brand new understanding and idea and cultivate their ability to analyze and solve problems through reflection, discussion, exploration and practice" (Wang Qiang, 2003: 76). Thinking here refers to the students critical thinking skills. Therefore, in College English teaching, we should enhance the students' innovative consciousness and competence, strengthen practical teaching links, and improve students' critical thinking and communication skills, so as to meet the needs of the times and the demands of society for talents. Moreover, foreign language teaching in universities and colleges is directly related to whether we can bring up talents with cross-cultura communicative competence, comprehensive cultural quality and international vision, all of which are the key capabilities under the trend towards increasingly frequent international exchanges.

The College English Curriculum Requirements published in September 2007 determined that the current goal of college English teaching in our country is to develop students' comprehensive abilities in English, especially listening and speaking abilities to ensure their effective communications in the future. Meanwhile, we should enhance their autonomous learning ability and improve their overall cultural literacy in order to adapt to the needs of China's economic development and international exchanges. 
Furthermore, the requirements also clearly pointed out that colleges and universities should take full advantage of the opportunities brought by the development of multimedia and network technology, and college English teaching must rely on modern network technologies and improve its efficiency under the network environment. According to the requirements, the new type of teaching pattern should lead English teaching towards a new way which is more individualized, autonomous and free from time and place restrictions. Obviously, in the future, the college English teaching reform should turn to develop an all-round and multi-dimensional interaction teaching mode combined with computer network teaching and classroom teaching. All in all, it is new issues for foreign language teaching workers to integrate the ever-changing information technology into interactive teaching, constructs a new interactive model of foreign language learning under the environment of computer network, and makes full use of network resources to promote language learning.

\section{THEORETICAL BASIS FOR COLLEGE ENGLISH TEACHING}

Constructivist learning theory claims that knowledge is not taught by teachers, but acquired by learners themselves in a certain context, social and cultural context, with the help of other people, including teachers and learning partners, with the use of the necessary learning resources, through meaning construction. "situation", "cooperation", "conversation" and "significance construction" are four main factors in study environment, which highlights the role of interactions during the process of constructive learning, calls for multidirectional exchanges and discussions between teachers and students and among students or solving problems by the form of collaboration, and encourages cooperative learning and learning from each other. (He Keqiang,1997:4). The theory emphasizes the role of students in the learning process, and stresses that teachers should make full use of the abundant teaching resources and flexible teaching methods, to help students construct knowledge and to make students change their thought pattern from "they want me to learn" to "I want to learn". Therefore, teachers should create a realistic environment through multimedia technology and an atmosphere of innovative thinking to cultivate students' sense of innovation and stimulate their imagination.

As for multi-dimension teaching theory, it is a multidimensional network-based foreign language teaching mode combined with information technology represented by computer networks and foreign language classroom teaching. Chen Jianlin (2011:5) generalizes the multi-dimensional teaching theory as a comprehensive and multi-polarized teaching method which lays emphasis both on training comprehensive foreign language skills, including listening, speaking, reading, writing and translation, and on interactions between teachers and students, and among students. The theory pays attention to the interrelation of the view of teaching, teaching model and teaching skills and their consistency, which forms the systematic development of teaching. The multi-dimensional teaching is a diversified and stereoscopic mode focusing on comprehensive application about multi-dimensional information input mode, self-driven mode, electronic interaction mode and culture awareness training mode. As modern multi-dimensional network technology is applied in multi-dimensional teaching mode, multi-dimensional teaching theory is an evolutionary process from static state to dynamic state with features of multi-mode, multi-view, multi-media, multi-medium and diversification. It integrates Listening, speaking, reading, writing and translating skills and combines the cultural, environmental and technological teaching theory. So, the multi-dimensional teaching theory just fits the needs of multi-dimensional interaction teaching mode of college English oriented by innovation, critical thinking and crosscultural communicative competence.

\section{CONNOTATION OF MULTIDIMENSIONAL INTERACTIVE TEACHING CONCEPT}

The multi-dimensional interactive teaching refers to the interaction and mutual influence between teachers and students, students and students, humans and machines under network environment. It is an all-round and multi-level meaning construction mechanism which aims at promoting learners' cognitive restructuring through bilateral exchanges and dialogues. It helps to form a stereoscopic Information exchange and transmission web between four teaching elements including teachers, students, textbooks and the multimedia. Under the comprehensive function of multimedia and network-based teaching, learners are brought into the real target-language environment, so that they can apply their linguistic knowledge into practice and train their listening, speaking, reading and writing skills. As a result, they will truly master the language knowledge and skills through observing and imitating a series of language practical activities and through an iterative process of continual experimentation, exploration, operation, reflection and correction. (Zhu Hongyan, 2006:102) Multimedia network-based teaching not only creates a real autonomous learning environment for learners, but also establishes a broad space for teachers to play a leading role. With its flexibility, openness and the multi-dimensional nature, Multimedia network-based teaching has given teachers new responsibilities and new roles. It requires that teachers should take full account of the individual differences in the learning style, cognitive model, emotions and learning motivation while teaching: this teaching model will create a relatively authentic environment according to the teaching contents and schedule, so that learners could immerse in the exploration about real-world problems and tasks and do corresponding integration. It will help learners to construct knowledge and improve their cognitive level through the process of "learning by doing" and "doing by learning". Language learners are provided with a large number of latest and targeted language learning resources with different levels of difficulty, which will lead learners to inquire knowledge initiatively. The learning process will be timely monitored by the network platform, thus teaching method will be rearranged dynamically and students will get effective guidance. 


\section{LANGUAGE ACQUISITION PROCESS OPTIMIZATION THROUGH MULTI-DIMENSIONAL LANGUAGE OUTPUT}

The multi-dimensional interaction consists of language input and output, which emphasizes the bidirectional and multi-directional nature of information processing, and highlights the significance of knowledge consultation, reasoning and construction among teaching subjects. In this sense, interaction is regarded as the essence of language use in language teaching activities. The positive meaning of the Input Hypothesis (Krashen, 1981:33) is that a lot of input will benefit the cultivation of new types of thought patterns and language skills. While, the Output Hypothesis shows that inputting is not the sufficient condition for language acquisition and outputting is an indispensable part in language acquisition, which is of great significance for college English teaching. In foreign language teaching, however, second language input mainly comes from the classroom and its quantity and quality is far below the ideal. Meanwhile, learners are unable to pay sufficient attention to the limited second language at any time. All of these reasons lead to more limited information intake. Therefore, given that second language input is severely limited, we should strengthen the salience of input information for the purpose of drawing more attention of learners. All in all, for the new type of interactive foreign language learning mode based on computer networks, input should be enhanced by certain methods, for instance, we can highlight some special items among input information, which can improve effective input by increasing the probability that targeted items can be noticed perceived. In the positive and negative feedback of teachers and students, the students' innovation, critical thinking and cross-cultural communicative competence can be developed.

\section{RESEARCH ON CONSTRUCTING MULTI-DimENSIONAL INTERACTION TEACHING MODE OF COLLEGE ENGLISH}

The practice of multi-dimensional interaction teaching mode of college English is a process of dynamic coordination and benign interaction among many factors including learners, teachers, teaching tasks, teaching environment, teaching policy and so on. Thus, the core feature of multi-dimensional interaction teaching mode of college English is the fusion of all the teaching factors. This teaching mode breaks the monotonous classroom teaching structure and realizes its dynamic nature and openness, which emphasizes on the students' language practice and the combination of the teaching function of foreign language class and the students' autonomous learning ability. And, the chance of students' participation is increased and an oral practice environment and an active atmosphere are incubated. Furthermore, this mode can create conditions for students' language input and output in many aspects and improve their oral expression ability, so as to cultivate students' innovation, critical thinking and cross-cultural communicative competence.

The teaching model can be summarized as the following major links:

- Creating a situation, arousing students' interest
- Explaining key points

- Intra-group and inter-group discussion and debate around the theme

- Presentation (through designing questionnaires, making surveys, doing interviews, verbal description, making PPT courseware and so on)

- Autonomous learning and inquiry questions

- Evaluation (including self-evaluation, peer assessment and teacher evaluation)

\section{- Homework Submission}

Scenario Creation and Excitation of Interest: Scenario creation means that teachers, according to the teaching objectives and curriculum content, create realistic learning situations related to the current theme of study and stimulate students' interest in learning, desire and divergent thinking with maximum efficiency, which can arouse their interest in the topic and, more importantly, their thirst for knowledge.

Therefore, teacher is not the educator of knowledge but the designer and organizer of the class, whose duty is mainly to design some interesting, expandable, scientific and practical topics for students, to organize, observe and guide students to enlighten them in the process of subject study, and to encourage students to think independently and propose unique insights. In this way, students' thinking skills can be trained effectively in originality, speculation and communicative competence.

Subject-based teaching will completely change the existing relationship between teachers and students in the classroom, students as the main body with a consistently active mind. In subject-based teaching, teachers are required to adjust teaching content to the theme of the text and design specific topics which can attract students' attention and combine knowledge and skills together. Once a subject is fixed, students will make full use of various teaching resources, such as libraries and Internet, to search, analyze, organize, reorganize and study relevant information. They can rethink, be hit by insight and awaken themselves in the study of small subjects in and out of class. Besides, in the cooperation with others, they are required to speak in English, which can help them apply language skills flexibly in the textbook to practical communication problems. What's more, teachers can also allow students to critically analyze the content in the textbook. Not only can they learn language knowledge, but their ability to use the language and their ability to think creatively can also be improved.

With a right understanding of its content, teachers and students should make the theme of each unit clear. Then teachers should arrange different teaching activities according to various themes, in which students are encouraged to present their ideas and discuss with each other in a multi-modal way, such PPT and other multimedia technologies. At the same time, in order to motivate their passions for participating in class to learn English, students are allowed to study actively and inquiringly (in class). In the process of guiding students to fully realize the importance of 
cultural background to language, teachers should consciously cultivate and improve students' intercultural awareness and develop their intercultural communication skills.

Taking Five Famous Symbols of American Culture (the fourth unit of "The New Horizons of College English" Reading and Writing Course Volume III) for example, teachers should make full use of information technology, multimedia and multi-mode when designing the PPT. First of all, teachers can list some pictures of world famous architectures, such as the Great Wall, the Eiffel Tower, Big Ben, the Sydney Opera House, the Leaning Tower of Pisa, and the Pyramids. Once seeing these pictures, they will immediately think of the corresponding countries because these buildings, as the crystallization of human wisdom, are the most powerful represent of each culture. Then, play an only 2-minute long video of the Statue of Liberty and let students watch it and write down the main information of it, which can give them a solid and vivid understanding of the Statue of Liberty. Next comes the presentation part. Under the teachers' instructions, students introduce their prepared PPTs of the image of Uncle Sam, buffalo nickel and the early colonial history of the United States in groups, and then discuss American culture with each other. In activating students' creative thinking, multimedia, combining texts, images, audio and video together, is so illustrative, various, interesting and full of knowledge that it can provide students with a vivid teaching situation and colorful teaching resources. With the application of multimedia, a staticdynamic teaching situation is created, which can stimulate students' many organs at the same time, such as brain, eyes, ears, hands and mouth, and encourage them to think, remember, associate and explore things actively. And finally, for students, the automatic learning will replace the passive learning.

\section{APPLICATION OF SOCRATIC METHOD IN CLASS TO CUlTivate STUdENTS' INNOVATIVENESS, CRITICAL THINKING AND CROSS-CULTURAL AWARENESS}

The Socratic Method can create a free, relaxed and lively atmosphere of discussion, where students are encouraged to brainstorm to express their own creative ideas or questions and argue with each other. English teachers should take advantage of multimedia to activate students' innovative thinking, and constantly raise awareness of thinking training for students, and combine it with daily teaching in order to train students with excellent language quality and excellent critical thinking ability. For example, the theme for A Good Heart to Lean On, the third unit of "The New Horizons of College English" Reading and Writing Course Volume I, is Paternal Love, which teachers can explain in the following parts:

Design a proper Guide-link to arouse interest. Teachers can share some pictures and a 5-minute video showing family love with students to elicit their curiosity, which can drive them to think about teaching intention.

Adopt heuristic modes of teaching to enlighten students' creative critical thinking. When in teaching, in order to help students think and have a deep understanding, teachers should design several deeply interactional questions according to the teaching content. Taking the theme above for example, here are 6 relevant questions:

- What is your understanding of your father's love? What about your family's love?

- Do you think you are obedient to your father? IF yes, why?

- Do you quarrel with your father, sometimes? IF yes, why?

- In what kind of circumstances you argue with your father?

- If you differ from your father, what will you do?

- If you were a father one day, how can you show your spontaneous love to your child?

The first question introduces students into the discussion of the topic, followed by other five questions in Socratic Method so as to enlighten their thinking. Meanwhile, students are allowed to discuss in groups and communicate with each other including teachers. Through discussion, mutual evaluation, students can be inspired and motivated by each other so as to expand students' thinking space and enhance students' ability of innovation, thinking and language communication.

In the application of the evaluation system, teachers are required to score students according to their classroom performance, including drama shows, report presentations, answering questions, feedback, classroom discussions, speaking shows, and inter-group communications, which count for $40 \%$ of the final grade. A good use of these forty points can contribute to teachers' effective teaching. Not only can it promote interactions in class between teachers and students, students and students, but it also helps teachers to know the difficulties, interests and comprehension skills of students, in which interactions between teaching subjects in teaching process can be achieved. In this method, teachers can really focus on students' English listening and speaking to improve their enthusiasm for listening and speaking English, and improve students' comprehensive English ability in an all-round way. The details of the personalized and dynamic evaluation system are as follows: 
TABLE I. The Personalized ANd DynAmic Evaluation System

\begin{tabular}{|l|l|}
\hline Purpose & $\begin{array}{l}\text { Evaluating what student have acquired according to their understanding of the knowledge } \\
\text { and content of the class. }\end{array}$ \\
\hline Focus & Teaching process (to promote teachers to reflect on teaching effectiveness) \\
\hline $\begin{array}{l}\text { Characteristics of the } \\
\text { evaluation }\end{array}$ & $\begin{array}{l}\text { Making students become the hosts of learning through conducting self-assessment and } \\
\text { peer-evaluation }\end{array}$ \\
\cline { 2 - 2 } & $\begin{array}{l}\text { Cultivating students' critical thinking ability } \\
\text { Having various and extensive ways and content of evaluation }\end{array}$ \\
\cline { 2 - 2 } & Focusing on qualitative analysis \\
\cline { 2 - 2 } & Being a kind of study itself \\
\cline { 2 - 2 } & Being flexible and dynamic \\
\hline Effective feedback & The score of the evaluation is based on the performance of the assignments from teachers. \\
\hline
\end{tabular}

In order to make full and practical use of Internet in teaching, we, relying on modern educational technology, develop various second classroom activities, which can create different language environments and its practice environment. As a result, with the potential and interest inspired, students' enthusiasm can be also fully mobilized. In our university, an online teaching platform that meets the college English teaching requirement, and an online shared intercultural communication teaching resource base have been created, which wins high praise from both teachers and students for the convenience provided for them. Teachers and students can interact with each other online through various activities, such as weekly English Salon and dorm English presentation. What's more, students can study autonomously online and it's also convenient for teachers to assign homework, tutor students and answer their questions after class. Here are some specific examples. Taking the resource base of Chinese and western culture for example, students could view cross-cultural films and share their comments with others, in which way, drawn in western culture and language environment not available for them in their real life, students' interests can be motivated and further, comprehensive language skills of listening, speaking, reading, writing and translating, and intercultural communication ability can be fully improved. Besides, after class, teachers can arrange group discussions of a fixed theme for students in their virtual learning community. For another, students can watch whichever open course of world's top universities they are interested in under teachers' instructions so that they could touch authentic western culture. Only in this way, can their integrated English language competence get real improved.

\section{CONCLUSION}

The teaching mode of college English, which focuses on emphasizing and fully utilizing computer and information technology today, is reformed, oriented by informatization, network, digitization, intelligence and globalization. Therefore, the significance of the reform in this paper lies in that it deals with the rules of English language learning in the network times and college English teaching model of multidimensional interaction and the improvement of the efficiency of classroom teaching which is oriented by the innovation, critical thinking, intercultural communicative competence on the basis of the constructiveness and the multidimensional theory. What's more, this study aims to promote the reform in college English teaching by providing a new perspective and concept for researches of college foreign language teaching model and useful information for English teachers in the exploration of this model, which is expected to contribute to nowadays college English teaching reform. Meanwhile, the process of foreign language teaching should be diverse, dynamic, flexible and open. In this case, teachers are required to adopt proper teaching strategies or English teaching models, instead of one specific teaching method, according to various teaching content, teaching objectives, teaching environment and learning needs. As a result, in order to help students meet the requirement of national economy and the society for talents with creativity, critical thinking and intercultural communication skills, college English teachers should take full advantage of multidimensional interaction of multimedia network to create an open foreign language class system and a charming English class with intercultural communication environment, in which students can learn to put their English knowledge and skills into practice.

\section{REFERENCES}

[1] A S.B. An Analysis of College Education at the age of scientific advancement (Translated by D.C.T \& D.S.T, Trans)[M]. Hangzhou: Zhejiang Education Publishing House, 1987.

[2] Chen L. The Post-method Era of Foreign Language Teaching Method [J]. Journal of Foreign Language School of Shandong Normal University(English Primary Education), 2009 (3).

[3] Chen J.B. An analysis of Multi-content Class and Multimedia Teaching Method [J]. Media in Foreign Language Instruction, 2011, (6):3-8.

[4] Dong X.B. An Analysis of College English Teaching Oriented by Intercultural Education[J]. Heilongjiang Higher Education Research, 2006,(1)

[5] He K.K. Construction Principle: the Theoretical Basis of the Innovation of Traditional Teaching [J]. E-education Research, 1997(3). 2002.

[6] Huang R.Y. Construction Principle and Multimedia Foreign Language Teaching Mode[J]. Media in Foreign Language Instruction, 2000, (2):16-19.

[7] Department of Higher Education. College English Curriculum Requirements[Z]. Foreign Language Teaching and Research Press. 2007.

[8] Krashen - S. Second Language Acquisition and Second Language Leaning [M]. Oxford: Pergamon Press, 1981.

[9] Wang Q. English Teaching Methodology (Revision)[M]. Beijing: Higher Education Press, 2003.

[10] Zhu H.Y. A Research on Collaborative Teaching Mode in Multimedia Network Environment[J]. Foreign Language World, 2006, S1. 